\title{
VIABILITY, FATTY ACID COMPOSITION, AND STRUCTURE OF THE CORALline AlGa CORALLINA PILULIFERA
}

\author{
Ji-Young Kang ${ }^{1}$, Ianthe Marie P. Benliro², Ik-Joon Lee ${ }^{1}$, Ji-Young Chol' ${ }^{1}$, Jin JoO³, \\ Yoo Seong $\mathrm{ChOl}^{4}$, Dong Soo Hwang ${ }^{5}$ and Yong-Kı Hong ${ }^{1,2,6}$ \\ 'Department of Biotechnology, Pukyong National University, Namku, Busan, Korea \\ ${ }^{2}$ KOICA-PKNU International Graduate Program of Fisheries Science, Pukyong National University, Namku, Busan, Korea \\ ${ }^{3}$ Department of Applied Chemistry, Kyungpook National University, Bukgu, Daegu, Korea \\ ${ }^{4}$ Department of Chemical Engineering, Chungnam National University, Yuseonggu, Daejeon, Korea \\ ${ }^{5}$ Postech Ocean Science \& Technology Institute, Pohang University of Science \& Technology, Namgu, Pohang, Korea \\ ${ }^{6}$ Author for correspondence: ykhong@pknu.ac.kr
}

\begin{abstract}
The decrease in the seaweed flora in some rocky areas, known as algal whitening or barren ground, is associated with some species of coralline algae. To determine the biological characteristics of a representative species of branched coralline alga, the number of medullary tiers was counted and ranged from 12 to 16 . The $18 \mathrm{~S}$ rDNA, $p s b A$, and $r b c L$ genes were used to confirm the identification of Corallina pilulifera. Measuring viability using triphenyl tetrazolium chloride showed highly viability from December to January. Cultural conditions of $16^{\circ} \mathrm{C}, 16 \mathrm{~h}$ light: $8 \mathrm{~h}$ dark cycle, and $40 \mu \mathrm{E} \mathrm{m} \mathrm{m}^{-2} \mathrm{~s}^{-1}$ light intensity were optimal for maintaining the viability of the coralline alga for up to three days. The fatty acids included $31.4 \% \omega-3$ eicosapentaenoic acid. Scanning electron microscopy of the surface structure revealed unique round wells about $7.9 \pm 1.3 \mu \mathrm{m}$ in diameter. The coralline alga, preventing fleshy seaweeds, may be used as a potential template for the creation of new environmentally friendly biomimetic antifouling material against the attachment of soft foulants, especially micro- and macroalgae.
\end{abstract}

Key words: Corallina pilulifera, fatty acid, tissue structure, viability.

Resumen: La disminución de la flora de algas en algunas zonas rocosas , conocidas como el blanqueamiento de algas o de tierra árida, se asocia con algunas especies de algas coralinas. Para determinar las características biológicas de una especie representativa de alga coralina ramificada se contó el número de hileras medulares que varió de 12 a 16. Los genes $18 \mathrm{~S}$ rDNA, psbA y rbcL se utilizaron para confirmar la identificación de Corallina pilulifera. La viabilidad se medió utilizando cloruro de trifeniltetrazolio y ésta fue alta de diciembre a enero . Las condiciones de cultivo: $16^{\circ} \mathrm{C}, 16 \mathrm{~h} \mathrm{luz:}: 8 \mathrm{~h}$ oscuridad ciclo y una intensidad lumínica de $40 \mu \mathrm{E} \mathrm{m}^{-2} \mathrm{~s}^{-1}$ fueron óptimas para mantener la viabilidad de la alga coralina por un máximo de tres días. Los ácidos grasos incluyen 31.4\% de $\omega$-3 ácido eicosapentaenoico. La microscopía electrónica de barrido permitió observar la superficie tiene pozos redondos únicos de aproximadamente $7.9 \pm 1, .3 \mu \mathrm{m}$ de diámetro. El alga coralina, la prevención de algas carnosas, se puede utilizar como una plantilla para la creación de nuevo material anti-incrustante biomimético contra la unión de suciedades blandas, especialmente micro y macroalgas.

Palabras clave: ácidos grasos, Corallina pilulifera, estructura tisular, viabilidad.

$\mathbf{S}_{\mathrm{b}}^{\mathrm{e}}$ eaweed is an important source of food and shelter; its biomass takes up carbon in marine environments, and it is a source of chemicals for commercial applications (Thomas, 2002). Coralline red algae abound in nearshore areas and strongly influence the benthic community. When coralline algae are growing, the rock surfaces appear pink, while the fleshy seaweed flora disappears from the rocky areas. In marine environments, this phenomenon is generally called algal whitening, barren ground (Tokuda et al., 1994), coralline flats, or deforested areas. Now it is recognized as a natural hazard adversely affecting marine ecosystems and damaging commercial fishing areas. Although, biological (Kitamura et al., 1993; Agatsuma et al., 1997) and physical (Masaki et al., 1984; Johnson and Mann, 1986) factors may be sufficient to prevent the recruitment of fleshy seaweeds, allelopathic bromoform (Ohsawa et al., 2001) and fatty acid 
(Kim et al., 2004; Luyen et al., 2009) substances may also inhibit the settlement or germination of seaweed spores. Consequently, coralline algae may also prevent fouling by fleshy seaweeds. Biomimetics or biomimicry is known as a multidisciplinary subject for the design of materials and machines using the structure and function of biological systems as models. To invent antifouling materials in an environmentally friendly use, biologically inspired design of biomimetics of coralline structure and process would offer a creation of new material. For the production of biomimetic coralline, it is required to select the healthy coralline tissue as a template. In nature, most coralline algae are pink and have almost indistinguishable shapes. Seasonal changes in articulated coralline algae can also cause confusion, even in their identification (Baba et al., 1988; Akioka et al., 1999). Some polyunsaturated fatty acids (PUFAs) from crustose coralline have shown potent lytic activity against fleshy seaweed spores (Luyen et al., 2009). Therefore, in an attempt to make a biomimetic coralline alga material, we first had to identify the species that is used as a potential template, select the best conditioned tissues as standard material, analyze the fatty acid composition, and observe the fine surface structure.

\section{Materials and methods}

Plant material. Coralline algae were collected monthly from the rocky intertidal area at Cheongsapo $\left(35^{\circ} 09^{\prime} 28^{\prime \prime} \mathrm{N}\right.$, $\left.129^{\circ} 11^{\prime} 47^{\prime \prime} \mathrm{E}\right)$, on the east coast of Busan, Korea, during 2011 and 2012. The samples were transported in a container with seawater to the laboratory. After rinsing well with autoclaved seawater to remove epiphytes and debris, the tissues were sonicated three times with $30 \mathrm{~s}$ pulses of an ultrasonic water bath (low-intensity frequency of $90 \mathrm{kHz}$ ) to remove other microepiphytes.

Medullary tier. The coralline algae were fixed in SUSA solution ( $4.5 \mathrm{~g}$ mercuric choride, $0.5 \mathrm{~g}$ sodium chloride, $20 \mathrm{ml}$ $40 \%$ formalin, $4 \mathrm{ml}$ trichloroacetic acid, and $80 \mathrm{ml}$ distilled water) for $12 \mathrm{~h}$ and then transferred to formalin solution for $24 \mathrm{~h}$. The fronds were fixed for another $24 \mathrm{~h}$ in $10 \%$ neutral buffered formalin solution ( $100 \mathrm{ml} 40 \%$ formaldehyde, 800 $\mathrm{ml}$ distilled water, $4.0 \mathrm{~g}$ monosodium phosphate, and $6.5 \mathrm{~g}$ anhydrous disodium phosphate). The tissues were dehydrated through an alcohol series from 70 to $100 \%$ and cleaned with three changes of xylene. Specimens embedded in paraffin wax were cut at $5 \mu \mathrm{m}$ thickness with a rotary type microtome (Reichert-Jung 820; Leica, Wetzlar, Germany) and stained with hematoxylin and eosin (Clark, 1981).

Molecular identification. Approximately $0.2 \mathrm{~g}$ of the coralline alga was chopped into very tiny pieces and placed in a microtube. DNA was extracted using $\mathrm{LiCl}$, following Hong et al. (1995). The 18S rDNA gene, encoding the ri- bosomal RNA in the small subunit of eukaryotic cytoplasmic ribosome was amplified by polymerase chain reaction (PCR) with the universal primers $18 \mathrm{sF}$ (5'-CAACCTGGTTGATCCTGCCAGT-3') and 18sR (5'-GATCCTTCTGCAGGTTCACCTACGGAA-3'; Bird et al., 1992). The $p s b A$ gene encoding the D1 protein of the photosystem II reaction center complex in the photosynthetic organ was amplified by PCR with the primers $p s b A F$ (5'-ATTGCATTCGTTGCTGCTCCTC-3') and $p s b A R$ (5'-GTGAACCAGATTCCTACTACAGGC-3'; Kim et al., 2006). The $r b c L$ gene, known as RuBisCO or ribulose-1,5-bisphosphate carboxylase/oxygenase in photosynthesizing chloroplasts, was amplified by PCR with the primers rbcLF (5'-GCAGGTGAATCATCTACAGCAAC-3') and rbcLR (5'-GCTTGAATACCGTCTGGATGACC-3'; Freshwater et al., 1994). The PCR cycling parameters consisted of $94{ }^{\circ} \mathrm{C}$ for $5 \mathrm{~min}$, 30 cycles of $94^{\circ} \mathrm{C}$ for $30 \mathrm{~s}, 57^{\circ} \mathrm{C}$ for $30 \mathrm{~s}, 72^{\circ} \mathrm{C}$ for $1.5 \mathrm{~min}$, and one final $72{ }^{\circ} \mathrm{C}$ for $10 \mathrm{~min}$. The amplification products were sequenced using the same primers (SolGent, Daejeon, Korea). The sequences were edited and manipulated using MEGA3 (Kumar et al., 2004). Phylogenetic trees were inferred using the neighbor-joining algorithm (Saitou and Nei, 1987) in MEGA3 with bootstrap analysis of 1,000 bootstrap replications.

Viability assay. To measure the viability of the coralline tissue, the assay of Park et al. (2006) was used. Briefly, $1 \mathrm{ml}$ of $0.8 \%$ 2,3,5-triphenyltetrazolium chloride (TTC) in seawater containing $50 \mathrm{mM}$ Tris- $\mathrm{HCl}$ buffer $(\mathrm{pH} 8.0)$ was added to $0.05 \mathrm{~g}$ of tissue in a $1.5-\mathrm{ml}$ microtube and incubated in darkness for $1.5 \mathrm{~h}$ at $20^{\circ} \mathrm{C}$ under mineral oil. The triphenyl formazan that formed in the tissue was extracted with 0.6 $\mathrm{ml}$ of $0.2 \mathrm{~N}$ potassium hydroxide in $75 \%$ ethanol by heating for $15 \mathrm{~min}$ at $60^{\circ} \mathrm{C}$. The triphenyl formazan was quantified by measuring the absorbance at $475 \mathrm{~nm}$. To determine the optimal conditions for maintaining viability, $0.25 \mathrm{~g}$ of the tissue was cultured in $50 \mathrm{ml}$ of seawater under $40 \mu \mathrm{E} \mathrm{m}^{-2} \mathrm{~s}^{-1}$ light intensity on a $16 \mathrm{~h}$ light: $8 \mathrm{~h}$ dark cycle at $16^{\circ} \mathrm{C}$ for 3 days as the standard conditions.

Scanning electron microscopy. Healthy tissue collected on January 11, 2012 was washed with Milli-Q water (Millipore, Billerica, MA) and dried under vacuum before scanning electron microscopy (SEM) analysis. For SEM images, tissues were mounted on conductive carbon tabs of a SEM post (Ted Pella, Inc., Redding, CA), sputter-coated using a Desk-II coater equipped with a gold target (Alfa Aesar, Ward Hill, MA), and imaged in a scanning-electron microscope (JSM-6700F; JEOL, Tokyo, Japan). To determine the elemental composition of parts of the tissues, the tissues were analyzed using energy-dispersive X-ray spectroscopy. The standards for carbon, oxygen, and calcium were calcium carbonate, silicon dioxide, and wollastonite, respectively. 

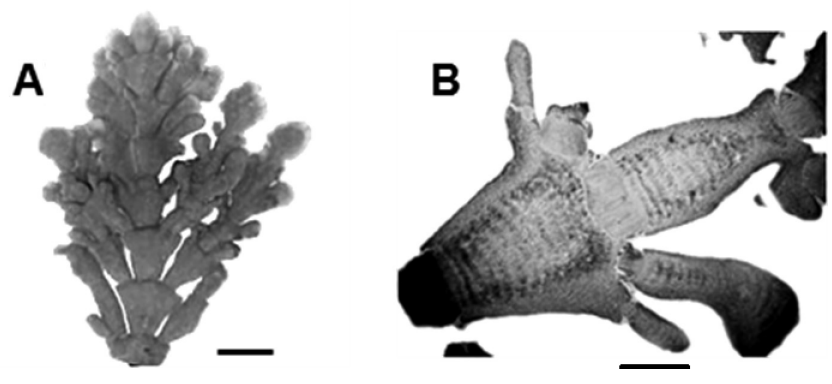

Figure 1. Tissue of the articulated coralline alga (A) and medullary tiers in longitudinal sections through the axial intergeniculum (B).

The bars in A and B indicate 2 and $0.8 \mathrm{~mm}$, respectively.

Fatty acid analysis. Fatty acids were determined by gas chromatographic quantification of their methyl esters (FAMEs), which were prepared using slightly modified method from the AOAC (2000). Total lipid was extracted from the dried samples using a Soxhlet extractor. Then, FAMEs were prepared with $5 \mathrm{ml}$ of methylation solution (1 sulfuric acid:20 methanol:10 toluene) and heated at $100{ }^{\circ} \mathrm{C}$ for 1 h. Gas chromatography-mass spectroscopy (GC-MS) analysis was conducted using a 6890 network GC system with a 5973N Mass Selective Detector (MSD) (Agilent Technologies, Palo Alto, CA). The oven was started at $50{ }^{\circ} \mathrm{C}$ and held for $1 \mathrm{~min}$, and then ramped up to $320^{\circ} \mathrm{C}$ at $5{ }^{\circ} \mathrm{C} \mathrm{min}{ }^{-1}$. The MSD was operated based on electron ionization.

\section{Results}

Eight samples of dominant coralline algae from different barren grounds and different seasons were collected. They were pinkish to reddish with a whitish apex and were gene- rally characterized by their calcareous composition (Figure 1A). They typically colonized rocky substrates and formed turfs in the intertidal area exposed to waves. The number of medullary tiers per intergeniculum and other characters were observed after staining with hematoxylin and eosin (Figure 1B). The number of tiers of medullary cells per intergeniculum was between 12 and 16 . The intergenicular length was approximately $1.0-1.4 \mathrm{~mm}$. The alga had pinnate fusing branches that were somewhat fan-shaped, with broad intergenicula, and truncated at the ends. The main base of the branch was almost as wide as it was long and the branches were somewhat subspherical. The frond height ranged from $3-7 \mathrm{~cm}$. To ascertain the species identification, we determined partial $18 \mathrm{~S}$ rDNA, $p s b A$, and $r b c L$ gene sequences. They were then aligned and analyzed using the neighbor-joining method to construct a dendrogram. The 1,156-bp 18S rDNA sequence from base 412 to 1,567 was compared to the sequences of 20 species of coralline algae obtained from the NCBI database to infer the phylogenetic relationships (Figure 2A). The $18 \mathrm{~S}$ rDNA sequence had 99\% homology with the Corallina sp. sequence (GenBank accession \# FM180100.1). Similarly, the 881-bp psbA plastid gene sequence from base 31 to 911 was compared with the sequences of 14 species of coralline algae obtained from the NCBI database (Figure 2B). The $p s b A$ gene sequence shared $100 \%$ homology with the Corallina pilulifera sequence (GenBank accession \# DQ787634.1). Likewise, the 943-bp $r b c L$ plastid gene sequence from base 226 to 1,168 (Figure 2C) shared 100\% homology with the C. pilulifera sequence (GenBank accession \# DQ787558.1). Therefore, the species was identified as the articulated coralline alga C. pilulifera using $18 \mathrm{~S}$ rDNA, $p s b A$, and $r b c L$ gene identification. Using the TTC method, we measured the viability
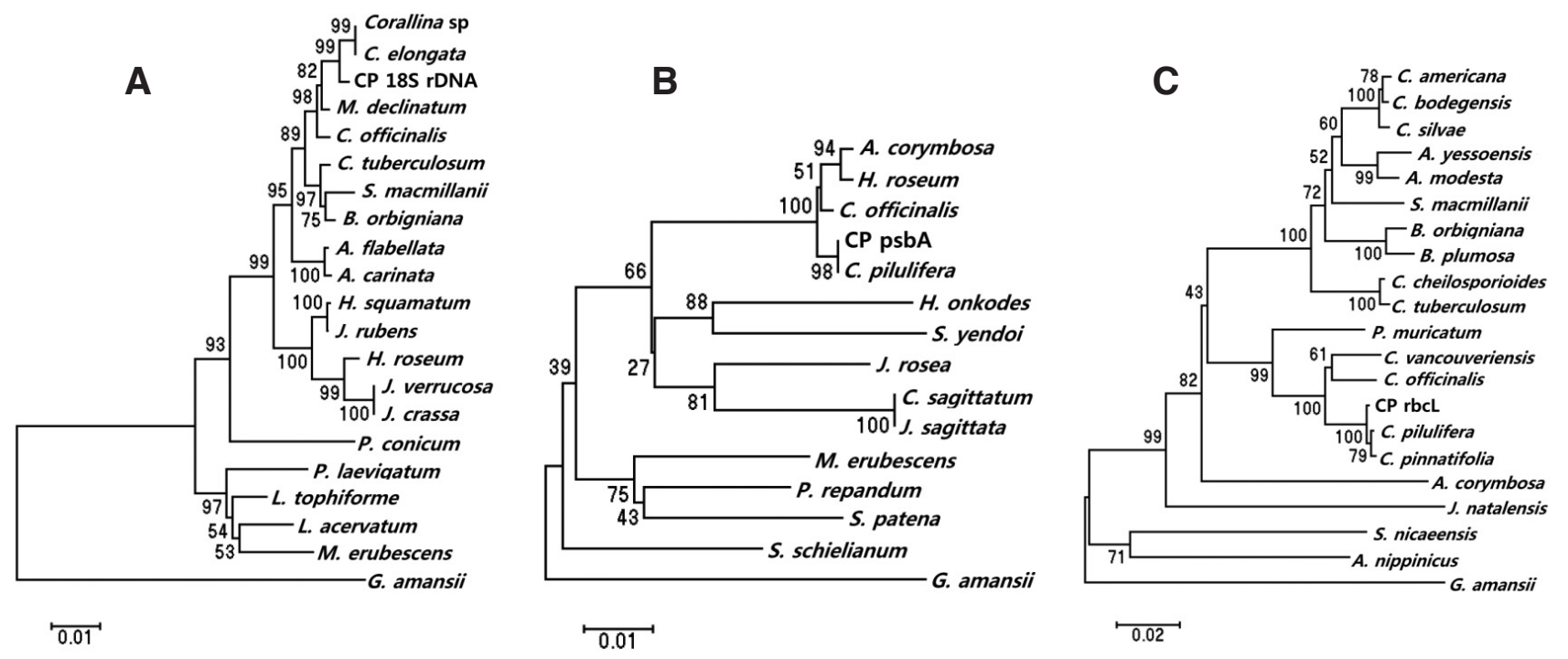

Figure 2. Phylogenetic dendrograms of the coralline alga (CP) based on $18 \mathrm{~S}$ rDNA (A), psbA (B), and $r b c L(\mathrm{C})$ sequences, and constructed using the neighbor-joining method. Numbers at nodes indicate the level of bootstrap support (1,000 replicates). 


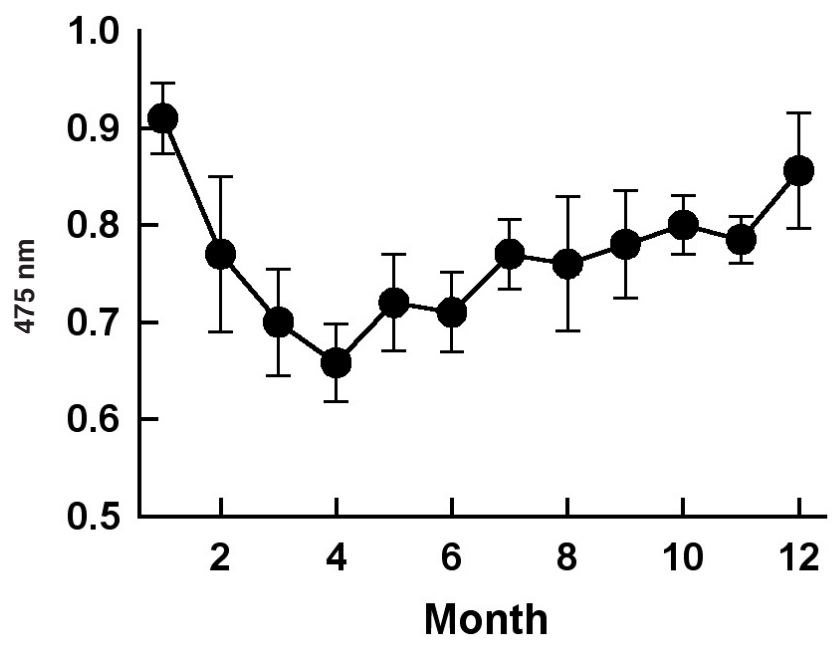

Figure 3. Seasonal variation in the viability of Corallina pilulifera tissue. The viability was quantified using the absorbance at 474 $\mathrm{nm}$, and the values are the mean \pm s.d. of at least five independent assays.

of $C$. pilulifera tissues collected at the same site throughout the year (Figure 3 ) and quantified viability as the absorbance at $545 \mathrm{~nm}$. The tissues collected in January had the greatest via-
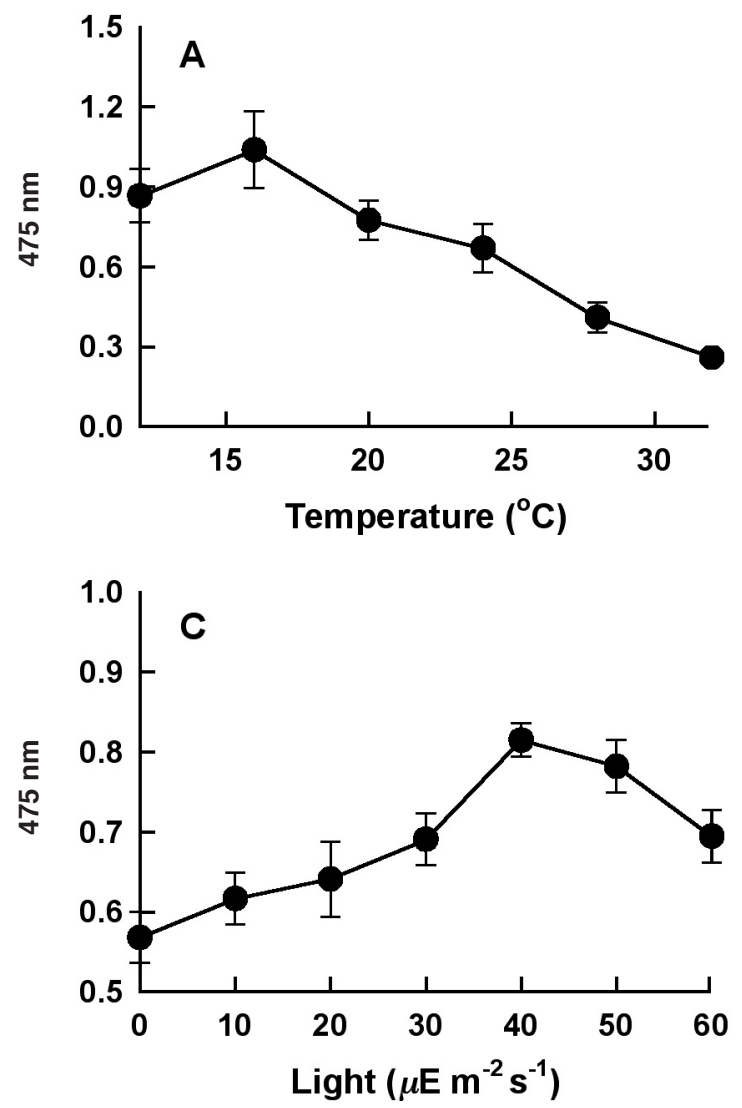

bility, which then decreased gradually in the spring. Some tissues remained short or as unbranched fronds, and some disappeared from the rock surface. In late spring and summer, new buds appeared on epilithic basal crusts. In autumn, they started to grow, and most tissues recovered their viability. In December and January, the tissues again had the healthiest pink structure and greatest viability. Therefore, this period would be the best season to use as a model structure of a biomimetic antifouling material. To keep healthy tissues, we optimized the maintenance conditions using the TTC viability assay (Figure 4). The optimal temperature for incubation was $16^{\circ} \mathrm{C}$, the optimal light intensity was $40 \mu \mathrm{E}$ $\mathrm{m}^{-2} \mathrm{~s}^{-1}$ with white fluorescent light, and the optimal light period was a $16 \mathrm{~h}$ light:8 $\mathrm{h}$ dark cycle. Under these conditions, the tissues maintained the best viability for up to three days in a standing flask containing natural seawater. Therefore, the tissues were kept at the optimized conditions and used within three days. We determined the major fatty acid composition of healthy $C$. pilulifera tissue (Table 1). Of the fatty acids, $45.4 \%$ were PUFAs, with $\omega-3$ eicosapentaenoic acid (EPA; C20:5) comprising 31.4\%; the $\omega-6: \omega-3$ ratio was 0.45 . The surface structure of the coralline tissue was examined using SEM. The tissue surface was covered with
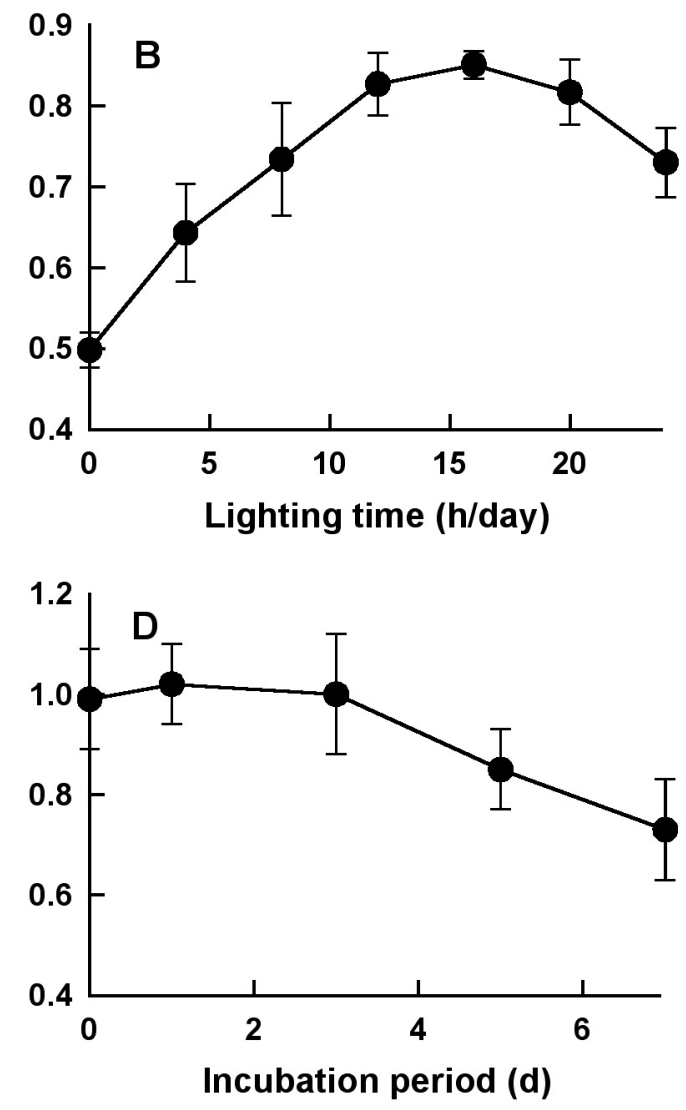

Figure 4. Effect of various parameters on the optimal maintenance of Corallina pilulifera tissue: A. incubation temperature, B. amount of light per day, C. light intensity, and D. incubation period under the optimized conditions. The viability was measured using the absorbance at $474 \mathrm{~nm}$, and the values are expressed as the mean \pm s.d. of at least five independent assays. 
Table 1. Profile of the major fatty acids (\% of total fatty acids) in CoraIlina pilulifera tissue collected on December 22, 2012.

\begin{tabular}{lc}
\hline Fatty acids & Relative amount $(\%)$ \\
\hline C14:0 & 1.9 \\
C16:0 & 28.8 \\
C18:0 & 6.3 \\
C18:1 $\omega-9$ & 1.7 \\
C18:2 $\omega-6$ & 3.8 \\
C18:3 $\omega-6$ & 1.5 \\
C20:4 $\omega-6$ & 5.3 \\
C20:5 $\omega-3$ & 31.4 \\
C22:0 & 4.5 \\
C22:2 $\omega-6$ & 2.3 \\
C24:0 & 1.5 \\
Saturated fatty acids & 50.7 \\
PUFAs & 45.4 \\
\hline
\end{tabular}

unique round dimples about $7.9 \pm 1.3 \mu \mathrm{m}$ in diameter at the surface (Figure 5). Most of these dimple-shaped structures were irregular circles, forming cones vertically. SEM-based energy-dispersive X-ray spectroscopy showed that the relative elemental composition was $33 \%$ carbon, $56 \%$ oxygen, and $11 \%$ calcium by atomic percentage, or $23 \%$ carbon, $53 \%$ oxygen, and $24 \%$ calcium by weight.

\section{Discussion}

The species Corallina pilulifera was identified using anatomical characters, such as the tier number per intergeniculum (12-16) and intergenicular length (0.9-1.2 mm; Baba et al., 1988; Akioka et al., 1999). All eight samples of the coralline algae collected had the same range of tier numbers, which is a key character of $C$. pilulifera. Slight differences in the

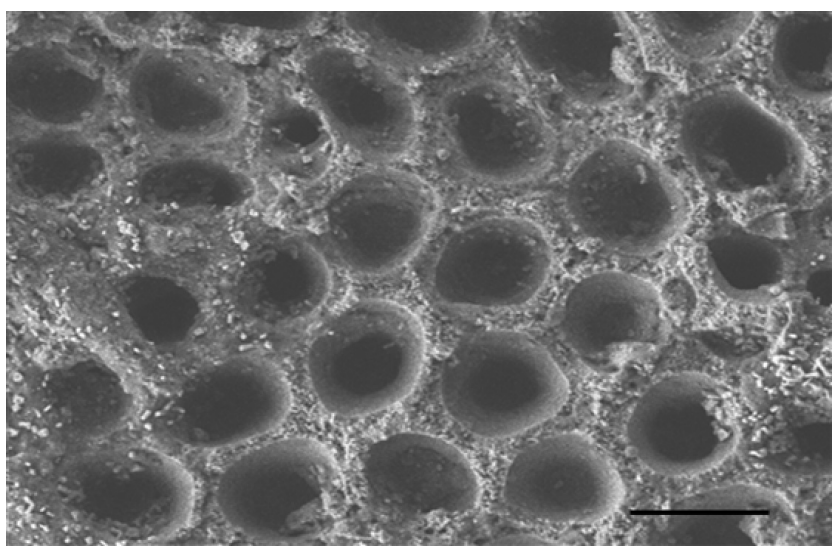

Figure 5. Scanning electron micrograph of Corallina pilulifera tissue. Bar $=10 \mu \mathrm{m}$. intergenicular length, width, frond height, branch, conceptacle, and intergenicular shapes were seen. Guiry and Guiry (2012) included four varieties of C. pilulifer $a$ and 29 entries of $C$. officinalis in AlgaeBase that were classified as uncertain. Morphological studies alone no longer suffice to identify species, as demonstrated by the apparent duplication of descriptions due to geographical, seasonal, and environmental differences. Differences in microhabitat conditions, such as desiccation, epiphyte loading, and the abundance of herbivores, can also alter the morphology (Akioka et al., 1999). Therefore, we used molecular information to complement the physical variation. Molecular analysis based on $18 \mathrm{~S}$ rDNA has been used to elucidate the division of Corallinoideae (Walker et al., 2009), the classification of the order Corallinales with 35 species of coralline algae (Bailey and Chapman, 1998), and the relationships within the tribe Janieae (Kim et al., 2007). The evolutionary history of the Corallinales has also been inferred from nuclear, plastidial, and mitochondrial genomes (Bittner et al., 2011). In this work, the species was identified as the $C$. pilulifera using tier numbers, even without reproductive structures and characteristics, but with complementary support of $18 \mathrm{~S}$ rDNA, $p s b A$, and $r b c L$ gene sequences.

Among the factors preventing the settlement or germination of fleshy seaweed spores, we found that PUFAs have potent lytic activity against algal spores (Luyen et al., 2009). When preparing biomimetic coralline alga material, the antifouling activity could be enhanced by adding bioactive PUFAs. The fatty acids from healthy Corallina pilulifera tissue, $31.4 \%$ were $\omega-3$ eicosapentaenoic acid (EPA; C20:5) and $14 \%$ were the other PUFAs. In a previous study, EPA showed strong lytic activity against algal spore with $\mathrm{LC}_{50}$ $=2.1 \mu \mathrm{g} \mathrm{ml}^{-1}$ (Luyen et al., 2009). Therefore, the preparation of biomimetic calcium carbonate nanoparticles with EPA is suggested to have potent antifouling activity as an environmentally friendly biocontrol. The mineral content of C. pilulifera was $28.5 \%$ carbonate, $18.4 \%$ calcium, $4.37 \%$ magnesium, $1.75 \%$ chloride, $0.31 \%$ iron, and $0.13 \%$ sodium (Yan, 1999). These high levels of essential minerals, especially calcium, magnesium, and iron, coupled with the low chloride, sodium, and potassium contents, make this species a potential mineral source for livestock, and further support this mineral composition as an environmentally friendly material.

Corallina pilulifera is an articulated coralline alga with a hard, abrasive calcareous skeleton. It dominates the intertidal zone on rocky substrate where strong waves occur. It produces a bromoperoxidase that acts on bromide and iodide, and the enzyme is potentially useful as a catalyst for biotransformation (Itoh et al., 1985). The allelopathic bromomethane released by the alga can eliminate epiphytic organisms, and might induce the continuation of coralline flats in marine environments (Ohsawa et al., 2001). Similarly, halogenated furanone compounds prevent biofilm forma- 
tion of bacteria on the algal body (Gram et al., 1996). Thus, addition of bromoperoxidase or halogenated compounds is recommended in the biomimetic material. The growth of the red tide microalga Prorocentrum donghaiense was inhibited by aqueous and methanolic extracts of $C$. pilulifera (Wang et al., 2007). The methanolic extract of $C$. pilulifera also had an antioxidant protective effect on UVA-induced oxidative stress in human fibroblasts (Ryu et al., 2009). Its ethanol extract inhibited the growth of the HeLa cancer cell line and induced apoptosis in a dose-dependent manner (Kwon et al., 2007). The tissue surface of the coralline alga was covered with dimples. A rough-surfaced sphere with small dimples experiences less drag than a sphere with smooth surface, same like dimpled golf balls fly farther than nondimpled balls. Fouling organisms or spores may be easily swept off and harder attached on the algal surface with dimples. Therefore, the information obtained from the C. pilulifera structure and antifouling substances can be used to make biomimetic materials and used as an environmentally friendly novel material to protect against the attachment of soft foulants, especially micro- and macroalgae.

\section{Acknowledgments}

This work was supported by the National Research Foundation of Korea Grant funded by the Korean Government (MEST) (NRF-C1ABA001-2012-0029960). We thank the Brain Busan 21 program for graduate scholarship (IJL) and three anonymous reviewers.

\section{Literature cited}

Agatsuma Y., Matsuyama K., Nakata A., Kawai T. and Nishikawa N. 1997. Marine algal succession on coralline flats after removal of sea urchins in Suttsu bay on the Japan Sea coast of Hokkaido, Japan. Nippon Suisan Gakkaishi 63:672-680.

Akioka H., Baba M., Masaki T. and Johansen H.W. 1999. Rocky shore turfs dominated by Corallina (Corallinales, Rhodophyta) in Northern Japan. Phycological Research 47:199-206.

AOAC. 2000. Official Methods of Analysis of the AOAC International. Vol II, 17th ed. Association of Official Analytical Chemists. Washington, DC.

Baba M., Johansen H.W. and Masaki T. 1988. The segregation of three species of Corallina (Corallinales, Rhodophyta) based on morphology and seasonality in northern Japan. Botanica Marina 31:15-22.

Bailey J.C. and Chapman R.L. 1998. A phylogenetic study of the Corallinales (Rhodophyta) based on nuclear small-subunit rRNA gene sequences. Journal of Phycology 34:692-705.

Bird C.J., Rice E.L., Murphy C.A. and Ragan M.A. 1992. Phylogenetic relationships in the Gracilariales (Rhodophyta) as determined by 18S rDNA sequences. Phycologia 31:510-522.

Bittner L., Payri C.E., Maneveldt G.W., Couloux A., Cruaud C., de Reviers B., Le Gall L. 2011. Evolutionary history of the Corallinales (Corallinophycidae, Rhodophyta) inferred from nuclear, plastidial and mitochondrial genomes. Molecular Phylogenetics and Evolution 61:697-713.
Clark G. 1981. Staining Procedures. 4th ed. Biological Stain Commission by Williams \& Wilkins, Baltimore.

Freshwater D.W., Fredericq S., Butler B.S., Hommersand M.H. and Chase M.W. 1994. A gene phylogeny of the red algae (Rhodophyta) based on plastid rbcL. Proceedings of the National Academy of Sciences of the United States of America 91:72817285.

Gram L., de Nys R., Maximilien R., Givskov M., Steinberg P. and Kjelleberg S. 1996. Inhibitory effects of secondary metabolites from the red alga Delisea pulchra on swarming motility of Proteus mirablis. Applied and Environmental Microbiology 62:4284-4287.

Guiry M.D. and Guiry G.M. 2012. AlgaeBase. <http://www.algaebase.org> (accessed May 2, 2012).

Hong Y.K., Kim S.D., Polne-Fuller M. and Gibor A. 1995. DNA extraction conditions from Porphyra perforata using LiCl. Journal of Applied Phycology 7:101-107.

Itoh N., Izumi Y. and Yamada H. 1985. Purification of bromoperoxidase from Corallina pilulifera. Biochemical and Biophysical Research Communication 131:428-435.

Johnson C.R. and Mann K.H. 1986. The crustose coralline alga, Phymatolithon Foslie, inhibits the overgrowth of seaweeds without relying on herbivores. Journal of Experimental Marine Biology and Ecology 96:127-146.

Kim M.S., Yang E.C. and Boo S.M. 2006. Taxonomy and phylogeny of flattened species of Gracilaria (Gracilariceae, Rhodophyta) from Korea based on morphology and protein-coding plastid $r b c L$ and $p s b A$ sequences. Phycologia 45:520-528.

Kim M.J., Choi J.S., Kang S.E., Cho J.Y., Jin H.J., Chun B.S. and Hong Y.K. 2004. Multiple allelopathic activity of the crustose coralline alga Lithophyllum yessoense against settlement and germination of seaweed spores. Journal of Applied Phycology 16:175-179.

Kim J.H., Guiry M.D., Oak J.H., Choi D.S., Kang S.H., Chung H. and Choi H.G. 2007. Phylogenetic relationships within the tribe Janieae (Corallinales, Rhodophyta) based on molecular and morphological data: a reappraisal of Jania. Journal of Phyco$\log y$ 43:1310-1319.

Kitamura H., Kitahara S. and Koh H.B. 1993. The induction of larval settlement and metamorphosis of two sea urchins, Pseudocentrotus depressus and Anthocidaris crassispina, by free fatty acids extracted from the coralline red alga Corallina pilulifera. Marine Biology 115:387-392.

Kumar S., Tamura K. and Nei M. 2004. MEGA3: Integrated software for molecular evolutionary genetics analysis and sequence alignment. Briefings in Bioinformatics 5:150-163.

Kwon H.J., Bae S.Y., Kim K.H., Han C.H., Cho S.H., Nam S.W., Choi Y.H. and Kim B.W. 2007. Induction of apoptosis in HeLa cells by ethanolic extract of Corallina pililufera. Food Chemistry 104:196-201.

Luyen Q.H., Cho J.Y., Choi J.S., Kang J.Y., Park N.G. and Hong Y.K. 2009. Isolation of algal spore lytic C17 fatty acid from the crustose coralline seaweed Lithophyllum yessoense. Journal of Applied Phycology 21:423-427.

Masaki T., Fujita D. and Hagen N.T. 1984. The surface ultrastructure and epithallium shedding of crustose coralline algae in an 'Isoyake' area of southwestern Hokkaido, Japan. Hydrobiologia 116/117:218-223.

Ohsawa N., Ogata Y., Okada N. and Itoh N. 2001. Physiological function of bromoperoxidase in the red marine alga, Corallina 
pilulifera: production of bromoform as an allelochemical and the simultaneous elimination of hydrogen peroxide. Phytochemistry 58:683-692.

Park S.M., Kang S.E., Choi J.S., Cho J.Y., Yoon S.J., Ahn D.H. and Hong Y.K. 2006. Viability assay of coralline algae using triphenyltetrazolium chloride. Fisheries Sciences 72:912-914.

Ryu B.M., Qian Z.J., Kim M.M., Nam K.W. and Kim S.K. 2009. Anti-photoaging activity and inhibition of matrix metalloproteinase (MMP) by marine red alga, Corallina pilulifera methanol extract. Radiation Physics and Chemistry 78:98-105.

Saitou N. and Nei M. 1987. The neighbor-joining method: a new method for reconstructing phylogenetic tree. Molecular Biology and Evolution 4:406-425.

Thomas D. 2002. Seaweeds. Smithsonian Institution Press, Washington, DC.

Received: January 9th, 2013

Accepted: May 10th, 2013
Tokuda H., Kawashima S., Ohno M. and Ogawa H. 1994. Seaweeds of Japan: a photographic guide. Midori Shobô Co., Tokyo.

Walker R.H., Brodie J., Russell S., Irvine L.M. and Orfanidis S.2009. Biodiversity of coralline algae in the northeastern Atlantic including Corallina caespitosa sp. nov. (Corallinoideae, Rhodophyta). Journal of Phycology 45:287-297.

Wang R., Xiao H., Wang Y., Zhou W. and Tang X. 2007. Effects of three macroalgae, Ulva linza (Chlorophyta), Corallina pilulifera (Rhodophyta) and Sargassum thunbergii (Phaeophyta) on the growth of the red tide microalga Prorocentrum donghaiense under laboratory conditions. Journal of Sea Research 58:189197.

Yan X. 1999. Assessment of calcareous alga Corallina pilulifera as elemental provider. Biomass and Bioenergy 16:357-360. 